\title{
Impact of Leader-Member Relationship Quality on Job Satisfaction, Innovation and Operational Performance: A Case in Vietnam
}

\author{
Thanh Hung NGUYEN ${ }^{1}$
}

Received: April 06, 2020 Revised: April 18, 2020 Accepted: May 01, 2020

\begin{abstract}
This study examines the relation between the quality of leader-member relationship and operational performance of processing enterprises employees in Vietnam, while job satisfaction and innovation are as a mediator variable. In depth interviews are first conducted with five managers and professional workers in five processing enterprises to determine the latent variables and build the structured questionnaire with observed variables. A quantitative survey with 438 employees and managers from 300 processing enterprises was carried out. The method of exploratory factor analysis (EFA), Cronbach's alpha analysis, and confirmatory factor analysis (CFA) was used to test the reliability, the convergent nature, and the consistency of the concepts. Structural equation modeling (SEM) is used to test the proposed model. The result shows that job satisfaction, innovation and operational performance have positive effects on the quality of leader-member relationship. The relationship between leaders and members had indirect impact on employee's operational performance via their job satisfaction and innovation, which illustrates a mediator role of job satisfaction and innovation for employees' performance. The findings of this study suggest that managers need to focus on developing relationship with employees to improve their satisfaction, innovation and performance.
\end{abstract}

Keywords : Leader-Member Exchange, Relationship Quality, Innovation, Operational Performance.

JEL Classification Code: M10, M11, M12, O31

\section{Introduction}

Human resources plays a key role as well as maintain competitive advantages for organizations (Wright et al., 1994). The development of human resources is reflected by an increase in skills, attitudes and employee motivation. These factors will improve productivity, contribute to revenue and profit growth, which is expressed as an improvement in the financial capacity of businesses (Gamage, 2007). In particular, the quality of leader-member relationship is expressed by sharing between employees and their direct managers (leader - member exchange (LMX)) which contributes to the participation of employees in achieving

${ }^{1}$ First Author and Corresponding Author. School of Economics and Law, Tra Vinh University, Vietnam [Postal Address: 126 Nguyen Thien Thanh Street, Hamlet 4, Ward 5, Tra Vinh Province, 940000, Vietnam] Email: nthung@tvu.edu.vn

(c) Copyright: The Author(s)

This is an Open Access article distributed under the terms of the Creative Commons Attribution Non-Commercial License (http://Creativecommons.org/licenses/by-nc/4.0/) which permits unrestricted noncommercial use, distribution, and reproduction in any medium, provided the original work is properly cited. the organization's goals (Macey \& Schneider, 2008). These relationships help enterprises increase resource retention, share risks, affect important attitudes and behaviors of leaders and organizational members (Hutt, Stafford, Walker, \& Reingen, 2000).

The theory of Demand for Resources (JD-R) (Bakker \& Demerouti, 2007) states that an organization's support helps to promote potential activities, build engagement with the organization and improve employee performance. In addition, leaders need to constantly innovate on internal products and processes ( Dorenbosch, van Engen, \& Verhagen, 2005). Yuan and Woodman (2010) argued that employees should be encouraged to innovate during in their work. Especially, processing enterprises, which always requires creativity and product innovation to meet increasing market needs.

With an idea derived from the importance of the relationship between leader-member relationship quality and employee performance, this study discusses the effect of LMX on innovative work behaviors, job satisfaction and operational performance at the processing enterprises in the South, Vietnam. 


\section{Literature Review and Hypotheses}

The relationship quality between supervisor and subordinate is often studied through the theory of LMX (Graen, G., \& Scandura, 1987; Graen, 2003). Highquality relationships reflect confidence, support and employee loyalty, otherwise they will show their mistrust of work, lack of respect and loyalty (Morrow, Suzuki, Crum, Ruben, \& Pautsch, 2005). Liden, Wayne and Sparrowe (2000) found that employees would spend more time in high quality LMX relationships and much more knowledge and leadership emotional support than low quality relationships.

High-quality relationship between subordinates and his or her direct manager, which contributes to psychological safety, assumes that the environment of the workplace is safe for interpersonal risk-taking (Scandura and Schriesheim, 1994; Halbesleben, 2010). Leaders in a strong relationship with employees, which promote the achievement of work objectives, stimulate personal development and increase employee engagement (G. B. Graen, Uhl-bien, \& Uhlbien, 1995). Graen (2003) suggested that, in term of highquality relationships people receive more of a leader's time, more direction information, and more emotional support than those who have low-quality relationships. A degree of mutual trust and respect characterizes the high-quality LMX relationships between managers and subordinates.

Leader-member relationship quality offers the participants intangible and tangible benefits: the immaterial benefits of communication with leaders (Hofmann \& Morgeson, 1999) and having relationships based on beliefs (Bauer \& Green, 1996). Tangible advantages include the impact decisions ( Scandura, Graen, \& Novak, 1986), empowerment (Liden et al., 2000), advancement in the workplace (Wakabayashi, Graen, Graen, \& Graen, 1988), and the advance in wages (Wayne, Liden, Kraimer, \& Graf, 1999). These create a positive atmosphere for employees, which leads to increased work satisfaction ( Gerstner \& Day, 1997). In addition, LMX is correlated with job performance (Bauer \& Green, 1996; Tran, Lee, Nguyen, \& Srisittiratkul, 2020). According to the social exchange theory, the benefits one receives from another will result in the return of this benefit in a process (Gouldner, 1960). Therefore, employee attitude will change thanks to how organization treat them and what organization's value gave them. The higher quality of relationship, the more likely the employee will exhibit greater performance in response to their obligations to the leader. Hypotheses:

H1: Leader-member relationship quality has a positive impact on job satisfaction

H2: Leader-member relationship quality has a positive effect on operational performance
The findings by Sheldon (1971) showed that job satisfaction and employee commitment to organization show not only organizational performance, but also employee performance on their workplace. Sy, Tram and O'Hara (2006), Bakiev (2013) and Mansour, Gara and Gaha (2014) have demonstrated that job satisfaction is proportional to firm performance. Hypothesis:

H3. Job satisfaction has a positive influence on operational performance

High-quality LMX characteristics describe leaders in good leadership style who are always supporting subordinates with challenge tasks, encouraging them to overcome risk environment and tackling tasks. These are conducive to promoting innovation behavior. Graen \& Scandura (1987) argued that high-quality LMX has a positive effect on innovation. Scott and Facdty (1994) showed that LMX and employee innovation behavior are positively correlated. Rubera and Kirca (2012) indicated that worker innovativeness has an indirect effect on corporate interest via its effects on market and financial positions.

García-Morales, Lloréns-Montes and Verdú-Jover (2008) showed that innovation is essential for improving performance, and that those organizations that focus on employee creativity are more successful in securing a larger market share and can generate high income and profits. Besides, the innovation should be the concern of managers in order to boost their operational performance (Hoang \& Ngoc, 2019). Employee innovation behavior is defined as behavior that can innovate, create ideas or give recommendations for their team. Thus, in replication of previous findings, we assume that:

H4: Leader-member relationship quality has a significant positive impact on employee's innovative behavior

H5: Innovative work behaviors are positively related to operational performance

The scales of each factor were taken from previous studies and modified for this study context.

RQ - Leader-member relationship quality in this study was measured by seven observed variables (Gómez and Rosen, 2001; Liden and Maslyn, 1998)

JOS - Job Satisfaction included five observed variables and the measurement was borrowed from (Homburg \& Stock, 2004)

INN - Innovation was developed from Janssen's (2000) and Lahiri (2010). Five items reflected the novelty and creativity of particular company's new ideas, products, processes, practices and management.

OP - Operational performance included seven observed variables which reflected employees' perception through 
criteria such as product quality, new products, the ability to attract labors, customers satisfaction, and the relationship between managers and employees (Dollinger \& Golden, 1992; Delaney and Huselid. Mark A., 1996)

Figure 1 displays the research model of this study.

\section{Research Methods}

\subsection{Research Sample}

The study deployed a convenience sampling technique to gather information from workers in 2019 in the south of Viet Nam. The sample size of this research comprised 438 employees at 300 processing enterprises. All items were evaluated using an ordinal 7-point scale, with responses ranging from total disagreement (point 1 on scale) to total agreement (point 7 on scale).

\subsection{Research Methods}

Both qualitative and quantitative research methods were employed in this paper. For qualitative research, at first, we studied the literature regarding latent variables to design the questionnaire. Then, we discussed with some experts who were managers in the Department of Industry and Trade and professionals who were executives in the processing companies to build the structured questionnaire with observed variables.

For quantitative research, Cronbach's Alpha was used to test the internal consistency of observable variables within a latent variable and to check the reliability of the factor scales; Exploratory Factor Analysis (EFA) was performed to determine the convergent nature of the concepts in the analysis; and Confirmatory Factor Analysis (CFA) was performed to test the presence of the observed variables and to confirm the concept relationship, which sought to demonstrate the consistency and unidimensionality of the concept. Structural Equation Modeling (SEM) was used to assess and calculate the component relationships in the research model.

\section{Results}

\subsection{Measurements and Scales}

Exploratory Factor Analysis (EFA): The EFA analysis in the preliminary study was conducted to eliminate variables that did not achieve discriminant validity and convergence validity. The analyzed results from EFA showed that TVEs of the concepts were greater than $60.0 \%$ of the variance and the KMO coefficient was greater than 0.5 , which confirmed that the variables in each factor contributed to higher partial interpretation and error.

The loading of the factors was greater than 0.4 , and the deviation between the load of factors was higher than 0.3. These factors all achieved convergence and matched the research model. Therefore, observed variables were accepted for inclusion in the formal analytical model.

Reliability measurement by Cronbach's Alpha: The results of the Cronbach's Alpha test showed the following scales to measure the concepts:

+ RQ - Relationship's leader-member exchange $(\alpha=$ 0.895 ) was measured by six items modified from (Gómez and Rosen, 2001; Liden and Maslyn, 1998) expectancy scale. RQ measurement which directly affected outcome expectations was employee's perception about her/his relationship with supervisor.

+ JOS - Job satisfaction $(\alpha=0.873)$ was measured by four modified from (Homburg \& Stock, 2004) which measured employees satisfaction in their work.

+ INN - Innovation $(\alpha=0.857)$ was evaluated using five Janssen's (2000) and Lahiri (2010) adapted items.

+ PEP - Operational performance was measured by five modified from (Dollinger \& Golden, 1992; Delaney and Huselid. Mark A., 1996)

Most of the concepts have Cronbach's alpha value greater than 0.60 and the Corrected Item-Total Correlation of variables greater than 0.3 . Therefore, the scales were reliable enough to be included in the EFA in the next step.

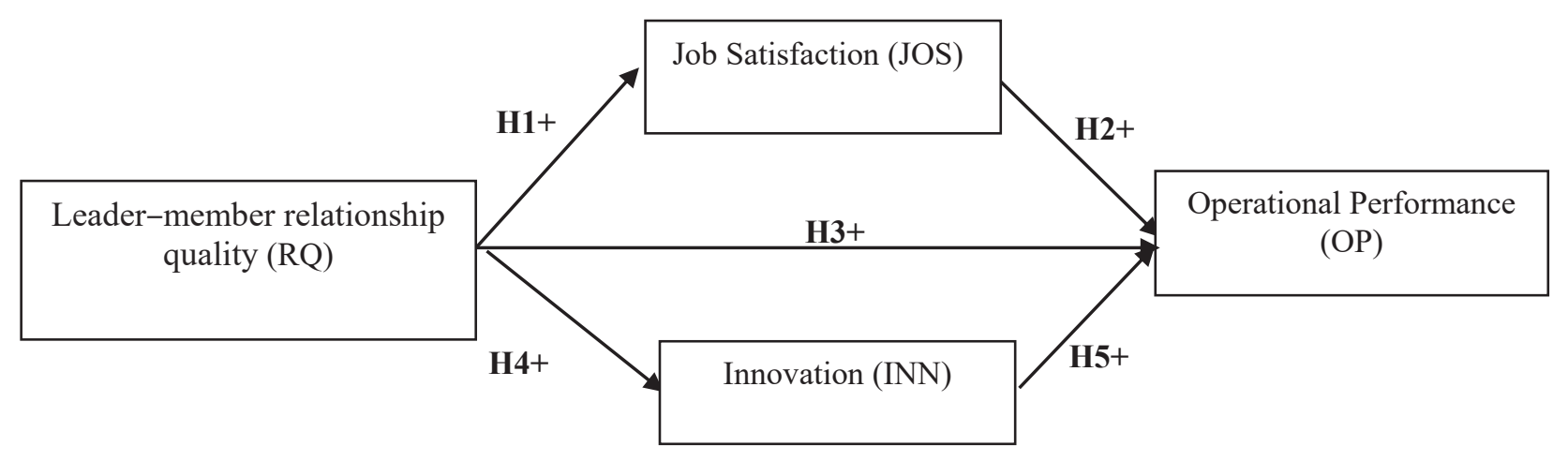

Figure 1. Research model 
Confirmatory Factor Analysis (CFA): CFA aimed at further clarifying aspects such as unidirectional, reliability of scales, convergent values, discriminant values, and the relevance of theoretical models to market data. The CFA results showed that Fit indexes indicated a good fit for the hypothesized model (Chi-square/ $\mathrm{df}=2.781 \leq 3$; RMSEA $=$ $0.065<0.08$; and the values GFI, TLI, CFI $\geq 0.90$ ). Hence, it was possible to affirm the items loaded significantly on the latent constructs they were designed to measure. The research model was consistent with real data (see Table 1).

\subsection{Results of Hypothesis Test}

Figure 2 shows the path analysis of the associated standardized regression weights. The analysis from the SEM shows that all indicators were satisfied including Chi-square/ $\mathrm{df}=2.912 \leq 3, \mathrm{RMSEA}=0.067<0.08$; and the values of TLI $=0.928, \mathrm{CFI}=0.938 \geq 0.90$. These indicators reflected that the model was consistent with the real data (see Figure 2). The estimated results (standardized) of the parameters of the research model (Table 2) shows that the relationships among concepts in the formal research model were statistically significant $(p<0.05)$. The significant threshold for this study was set at the P-value of 0.05 . In these tables the P-values, given as three asterisks $(* * *)$, refer to the $\mathrm{P}$-value of less than 0.001 . The estimation results showed that leader-member relationship quality (RQ) had the highest positive impact on job satisfaction in the processing enterprises.

Table 2 shows the factors of leader-member relationship quality, job satisfaction, innovation and operational performance. The table presents the effects of the predictions between the suggested variables along the respective paths.

Table 1: The findings of testing of scale reliability

\begin{tabular}{|c|c|c|c|c|}
\hline \multirow{2}{*}{ Concepts } & \multirow{2}{*}{$\begin{array}{l}\text { Observed } \\
\text { variables }\end{array}$} & \multicolumn{2}{|c|}{ Reliability } & \multirow{2}{*}{$\begin{array}{c}\text { Average Variance } \\
\text { Extracted (\%) }\end{array}$} \\
\hline & & Cronbach's alpha & Composite (pc) & \\
\hline $\begin{array}{l}\mathrm{RQ} \text { - Leader-member } \\
\text { relationship quality }\end{array}$ & 6 & 0.895 & 0.896 & 59 \\
\hline JOS - Job Satisfaction & 4 & 0.873 & 0.874 & 63 \\
\hline INN- Innovation & 5 & 0.857 & 0.857 & 55 \\
\hline OP - Operational performance & 5 & 0.865 & 0.866 & 56 \\
\hline
\end{tabular}

Chi-square $=474.590 ; \mathrm{df}=163 ; \mathrm{P}=.000 ;$ Chi-square $/ \mathrm{df}=2.912$

$\mathrm{GFI}=.893 ; \mathrm{TLI}=.928 ; \mathrm{CFI}=.938 ; \mathrm{RMSEA}=.067$

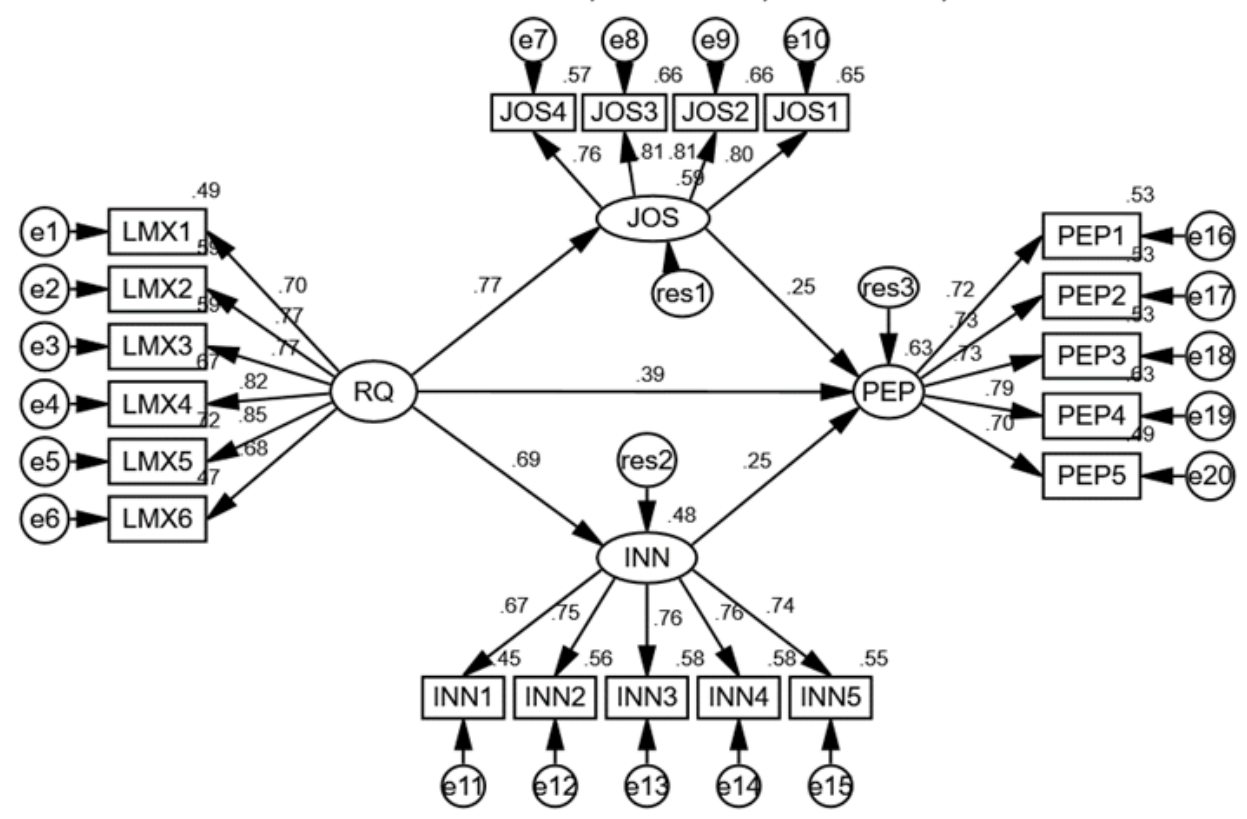

Figure 2. Data for the Hypothetical Paths 
All findings were significant and were in the path proposed. In accordance with existing research, RQ was positively associated with employee satisfaction and organizational innovation, the standardized b coefficient was 0.769 and 0.692 respectively $(\mathrm{p}<0.05)$. Hence, $\mathrm{H} 1$ and $\mathrm{H} 4$ were supported. In hypothesis 2 , RQ was related positively to operational performance, the standardized b coefficient was 0.387 ( $\mathrm{p}<0.05)$. H2 was also supported. Finally, the path coefficients indicated significant effects, which suggested that job satisfaction and innovation had a strong and direct effect on operational performance. This result supported hypothesis $\mathrm{H} 3$ and $\mathrm{H} 5$.

This research reflected both theoretical and managerial approaches to analyze the relationships between essential relational principles that were found in the literature, including relationship quality, job satisfaction, innovation, and operational performance. Furthermore, operational performance was explained with $\mathrm{R}^{2}=63.3 \%$. This finding suggested the possibility of related organizational performance to other variables, which were not covered by the model.

\section{Discussion and Implications}

\subsection{Discussion}

Findings from this study show an important role of the quality of the relationship between leaders and members, which help enhance creative participation in work performance and employees' job satisfaction contributing positively to operational efficiency. Arup (2005) suggested that employees in the collective culture judge highly the value of organizational hierarchy and have a greater need to connect and support (nurture), always seek the support of direct managers (Restubog, Bordia, Tang, \& Krebs, 2010) and need more protection and guidance than employees working in Western culture (Anand, S., Vidyarthi, P. R., Liden, R C., Rousseau, 2010). As employees receive encouragement and care from direct supervisors, this not only increases the organization commitment, it also improves operational performance (Nguyen \& Tu, 2020)normative commitment (NCO.

The positive effects of engagement in work and innovation behaviors, in line with Broaden-and-Build theory of positive emotions theory (Fredrickson, 2000), creates an expanded positive emotional experience for thinking action items, thereby increasing the likelihood of creative work behavior.

The findings emphasize that managers should constantly care and encourage employees in the enterprise to improve innovation (innovation is an important factor in the processing industry). This not only provide them with job satisfaction, but also improves organizational performance. Moreover, these results contribute significantly to the literature on leadership, it proves that LMX has a positive impact to the reaction and attitude of the employees.

\subsection{Implications for Managers}

To improve the relationship between leader-member relationship quality, leaders should interact and maintain exchanges with subordinate members. In particular, the leadership's dedication should be known by employees, such as contributing to the job; combining words and actions; setting strict requirements for themselves; supporting employees to create a friendly environment for development; paying attention to the development of employees, their families and their daily lives; and creating a sense of security for employee job.

Encouragement of employee's participation to the rules and procedures in the enterprise would ensure quality improvement and enhance the employees' contribution. As a result, it would improve the product quality to meet customers' needs, and contributing to improve market performance. Furthermore, operational performance would enhance management efficiency.

Table 2: Results of testing the relationship between concepts in theory model

\begin{tabular}{|c|c|c|c|c|c|c|c|c|}
\hline Hypothesis & \multicolumn{2}{|c|}{ Relationship } & Estimates & Standard error & Critical Ratios & P value & Evaluation \\
\hline $\mathrm{H} 1$ & $\mathrm{RQ}$ & $\rightarrow$ & JOS & 0.769 & 0.066 & 12.541 & $\begin{array}{c}\text { Hypothesis } \\
\text { supported }\end{array}$ \\
\hline $\mathrm{H} 2$ & $\mathrm{RQ}$ & $\rightarrow$ & $\mathrm{PEP}$ & 0.387 & 0.084 & 4.234 & $\begin{array}{c}\text { Hypothesis } \\
\text { supported }\end{array}$ \\
\hline $\mathrm{H} 3$ & $\mathrm{JOS}$ & $\rightarrow$ & PEP & 0.253 & 0.062 & 3.441 & $\begin{array}{c}\text { Hypothesis } \\
\text { supported }\end{array}$ \\
\hline $\mathrm{H} 4$ & $\mathrm{RQ}$ & $\rightarrow$ & INN & 0.693 & 0.067 & 11.09 & $* * *$ & $\begin{array}{c}\text { Hypothesis } \\
\text { supported }\end{array}$ \\
\hline $\mathrm{H} 5$ & $\mathrm{INN}$ & $\rightarrow$ & PEP & 0.254 & 0.054 & 3.98 & $* * *$ & $\begin{array}{c}\text { Hypothesis } \\
\text { supported }\end{array}$ \\
\hline
\end{tabular}


Besides, it is necessary and extremely meaningful to set up challenging jobs. Through it, leaders support employees to come up with innovative behavior at work. Moreover, business innovation mostly depends on employees, so leaders should pay attention to the organization's vision that can inspire, and describe their positive work in the future. In addition, let them know the growth prospects at their workplace.

Innovation at work is also expressed through the employees' willingness to do works that exceed expectations in their duties. Likewise, not only do leaders equip themselves with professional knowledge and skills, but also enable employees to confidently make bold efforts to innovate.

In addition, due to the influence of Asian culture, emotion is a crucial link in human relationships; it plays a key role in interpersonal communication. However, if the personal relationship between the leader and his subordinates are too close, these emotions can influence the decision-making of superiors and subordinates. Sometimes, to maintain that affection, they may become complacent because they do not want to disrupt the original situation. Consequently, a profoundly emotional relationship between leadership and subordinates may not be conducive to employee innovation, but also negatively affect business performance. For this reason, leaders should pay attention to the level of relationships with employees at work.

Besides, the organization of regular and informal subordinate meetings such as outings or festive meetings will result in enriching the quality of relationships between employees and managers. So, the managers should be interested in subordinates by remembering events important to employees such as job anniversaries, birthdays and family events.

For practical implications, it is recommended that leaders in processing enterprises should encourage employees to create and implement innovative ideas. Moreover, high quality relationship between leaders and subordinates lead to increasing the employee's innovative behavior as well as their trust in the leader. To sum up, we suggest that leaders provide benefit opportunities for employees to innovate and improve the leader-member relationship quality. When employees feel their job is satisfying, they will contribute more to the organization's success.

\section{References}

Anand, S., Vidyarthi, P. R., Liden, R C., Rousseau, D. M. (2010). Good citizens in poor-quality relationships: idiosyncratic deals as a substitute for relationship quality. Academy of Management Journal, 53(5), 970-988.

Arup, V. (2005). A comparative study of the impact of leadermember exchange in US and Indian samples. Cross Cultural
Management: An International Journal, 12(1), 84-95. https:// doi.org/10.1108/13527600510797971

Bakiev, E. (2013). The influence of interpersonal trust and organizational commitment on perceived organizational performance. Journal of Applied Business Research, 3(3), 166-180. Retrieved from www.aebrjournal.org/ uploads/6/6/2/2/6622240/4._erlan.pdf

Bakker, A. B., \& Demerouti, E. (2007). The Job DemandsResources model : state of the art. 22(3), 309-328. https://doi. org/10.1108/02683940710733115

Bauer, T. N., \& Green, S. G. (1996). Development of LeaderMember Exchange: A Longitudinal Test Author ( $\mathrm{s}$ ): Development of Leader-Member Exchange : A Longitudinal Test. Academy of Management Journal, 39, 1538-1567. https:// doi.org/10.5465/257068

Delaney, J. T., \& Huselid, M. A. (1996). the Impact of Human Resource Management Practices on Perceptions of Organizational Performance. Academy of Management Faarnal, 39(4), 949-969. https://doi.org/10.2307/256718

Dollinger, M. J., \& Golden, P. A. (1992). Interorganizational and Collective Strategies in Small Firms: Environmental Effects and Performance. Journal of Management, 18(4), 695-715. https://doi.org/10.1177/014920639201800406

Dorenbosch, L., van Engen, M. L., \& Verhagen, M. (2005). Onthe-job Innovation: The Impact of Job Design and Human Resource Management through Production Ownership. Creativity and Innovation Management, 14(2), 129-141. https://doi.org/10.1111/j.1476-8691.2005.00333.x

Fredrickson, B. L. (2000). Cultivating positive emotions to optimize health and well-being. Prevention \& Treatment, 3(1). https:// doi.org/10.1037/1522-3736.3.1.31a

Gamage, A. (2007). Impact of HRD Practices on Business Performance : An empirical analysis of manufacturing SMEs in Japan. Journal of Meijo, 85(11), 85-109.

García-Morales, V. J., Lloréns-Montes, F. J., \& Verdú-Jover, A. J. (2008). The effects of transformational leadership on organizational performance through knowledge and innovation. British Journal of Management, 19(4), 299-319. https://doi. org/10.1111/j.1467-8551.2007.00547.x

Gerstner, C. R., \& Day, D. V. (1997). Meta-Analytic review of leader-member exchange theory: Correlates and construct issues. Journal of Applied Psychology, 82(6), 827-844. https:// doi.org/10.1037/0021-9010.82.6.827

Gómez, C., \& Rosen, B. (2001). The Leader-Member Exchange as a Link between Managerial Trust and Employee Empowerment. Group and Organization Management, 26(1), 53-69. https:// doi.org/10.1177/1059601101261004

Gouldner, H. P. (1960). Dimensions of Organizational Commitment. Administrative Science Quarterly, 4(4), 468-490. https://doi. org/10.2307/2390769 
Graen, G. B., \& Scandura, T. A. (1987). Toward a Psychology of Dyadic Organizing. Research in Organizational Behavior, 9, 175-208.

Graen, G. B. (2003). Dealing with diversity. Champaign-Urbana, IL: IAP

Graen, G. B., Uhl-bien, M., \& Uhl-bien, M. (1995). DigitalCommons (a) University of Nebraska - Lincoln Relationship-Based Approach to Leadership: Development of Leader-Member Exchange (LMX) Theory of Leadership over 25 Years : Applying a Multi-Level Multi-Domain Perspective Relationship-Based Approach to. (LMX).

Hoang, C. C., \& Ngoc, B. H. (2019). The relationship between innovation capability and firm's performance in electronic companies, Vietnam. Journal of Asian Finance, Economics and Business, 6(3), 295-304. https://doi.org/10.13106/jafeb.2019. vol6.no3.295

Hofmann, D. A., \& Morgeson, F. P. (1999). Safety-related behavior as a social exchange: The role of perceived organizational support and leader-member exchange. Journal of Applied Psychology, 84(2), 286-296. https://doi.org/10.1037/00219010.84.2.286

Homburg, C., \& Stock, R. M. (2004). The Link Between Salespeople's Job Satisfaction and Customer Satisfaction in a Business-to-Business Context: A Dyadic Analysis. Journal of the Academy of Marketing Science, 32(2), 144-158. https://doi. org/10.1177/0092070303261415

Hutt, M. D., Stafford, E. R., Walker, B. A., \& Reingen, P. H. (2000). Case Study: Defining the Social Network of a Strategic Alliance. Sloan Management Review, 41(2), 51-62.

Janssen, O. (2000). Job demands, perceptions of eVortreward fairness and innovative work behaviour. Journal of Occupational and Organizational Psychology, 73, 287-302. https://doi.org/10.1016/j.aquaculture.2010.01.018

Lahiri, N. (2010). Geographic distribution of R \& D activity: How does it affect innovation quality? Academy of Management Journal, 53(5), 1194-1209. https://doi.org/10.5465/ amj.2010.54533233

Liden, R. C., \& Maslyn, J. M. (1998). Multidimensionality of leader-member exchange: An empirical assessment through scale development. Journal of Management, 24(1), 43-72. https://doi.org/10.1177/014920639802400105

Liden, R. C., Wayne, S. J., \& Sparrowe, R. T. (2000). An examination of the mediating role of psychological empowerment on the relations between the job, interpersonal relationships, and work outcomes. Journal of Applied Psychology, 85(3), 407-416. https://doi.org/10.1037/0021-9010.85.3.407

Macey, W. H., \& Schneider, B. (2008). The Meaning of Employee Engagement. Industrial and Organizational Psychology, 1(2008), 3-30. Available at: http://www.benschneiderphd.com/ Macey-Schneider_IOP_March_08.pdf

Mansour, N., Gara, E., \& Gaha, C. (2014). Getting inside the black box: HR practices and firm performance within the Tunisian financial services industry. Personnel Review, 43(4), 490-514.
Morrow, P. C., Suzuki, Y., Crum, M. R., Ruben, R., \& Pautsch, G. (2005). The role of leader-member exchange in high turnover work environments. Journal of Managerial Psychology, 20(December), 681-694. https://doi. org/10.1108/02683940510631444

Nguyen, T. H., \& Tu, V. B. (2020). Social responsibility, organizational commitment, and organizational performance: Food processing enterprises in the mekong river delta. Journal of Asian Finance, Economics and Business, 7(2), 309-316. https://doi.org/10.13106/jafeb.2020.vol7.no2.309

Restubog, S. L. D., Bordia, P., Tang, R. L., \& Krebs, S. A. (2010). Investigating the moderating effects of leader-member exchange in the psychological contract breach-employee performance relationship: A test of two competing perspectives. British Journal of Management, 21(2), 422-437. https://doi. org/10.1111/j.1467-8551.2009.00673.x

Rubera, G., \& Kirca, A. H. (2012). Firm innovativeness and its performance outcomes: A meta-analytic review and theoretical integration. Journal of Marketing, 76(3), 130-147. https://doi. org/10.1509/jm.10.0494

Scandura, T. A., Graen, G. B., \& Novak, M. A. (1986). When managers decide not to decide autocratically: An investigation of leader-member exchange and decision influence. Journal of Applied Psychology, 71(4), 579-584. https://doi. org/10.1037/0021-9010.71.4.579

Scandura, T. A., \& Schriesheim, C. A. (1994). Leader-member exchange and supervisor career mentoring as complementary constructs in leadership research. Academy of Management Journal, 37(6). https://doi.org/10.5465/256800

Scott, S. G., \& Facdty, M. (1994). Creating innovative behavior among $R \& D$ professionals: the moderating effect of leadership on the relationship between problem - solving style and innovation. 48-55. Proceedings of 1994 IEEE International Engineering Management Conference - IEMC '94.

Sheldon, M. E. (1971). Investments and involvements as mechanisms producing commitment to the organization. Administrative Science Quarterly, 143-150.

Sy, T., Tram, S., \& O'Hara, L. A. (2006). Relation of employee and manager emotional intelligence to job satisfaction and performance. Journal of Vocational Behavior, 68(3), 461-473. https://doi.org/10.1016/j.jvb.2005.10.003

Tran, D. T., Lee, L. Y., Nguyen, P. T., \& Srisittiratkul, W. (2020). How leader characteristics and leader member exchange lead to social capital and job performance. Journal of Asian Finance, Economics and Business, 7(1), 269-278. https://doi. org/10.13106/jafeb.2020.vol7.no1.269

Wakabayashi, M., Graen, G., Graen, M., \& Graen, M. (1988). Japanese management progress: Mobility into middle management. Journal of Applied Psychology, 73(2), 217.

Wayne, S. J., Liden, R. C., Kraimer, M. L., \& Graf, I. K. (1999). The role of human capital, motivation and supervisor sponsorship in predicting career success. 595(February 1997).

Wright, P. M., McMahan, G. C., \& McWilliams, A. (1994). Human resources and sustained competitive advantage: A 
resource-based perspective. The International Journal of Human Resource Management, 5(2), 301-326. https://doi. org/10.1080/09585199400000020

Yuan, F., \& Woodman, R. W. (2010). Innovative behavior in the workplace: The role of performance and image outcome expectations. Academy of Management Journal, 53(2), 323342. https://doi.org/10.5465/AMJ.2010.49388995 